\title{
PCR amplification of DNA from malaria parasites on fixed and stained thick and thin blood films
}

\author{
Dominic Edoh $^{1}$, Sylvia Steiger ${ }^{2}$, Blaise Genton $^{3}$ and Hans-Peter Beck $^{2}{ }^{1}$ Ifakara Centre, Ifakara, Tanzania; \\ ${ }^{2}$ Swiss Tropical Institute, Basel, Switzerland; ${ }^{3}$ Papua New Guinea Institute of Medical Research, Madang, Papua New \\ Guinea
}

\begin{abstract}
Under some circumstances, polymerase chain reaction (PCR) amplification of deoxyribonucleic acid (DNA) from Plasmodium may become necessary from infections for which only blood slides are available. Established methods used for DNA preparation do not work in that case. We have developed a reliable and controlled method for DNA preparation from malaria parasites on fixed and stained blood films. 162 slides from 2 different locations, some stored for at least one year, have been analysed by PCR amplification of the polymorphic loci for MSA1 and MSA2. In $92 \%$ of microscopically positive slides, a PCR product could be detected using material derived from thick blood films. When thin blood films with scanty parasitaemia were used, a PCR product could be obtained with only $71 \%$ of samples. In all unsuccessful cases, DNA preparation was the limiting factor, which was controlled for by amplification of a control human template.
\end{abstract}

Keywords: malaria, Plasmodium falciparum, polymerase chain reaction, blood films

\section{Introduction}

During the past few years, the polymerase chain reaction (PCR) has become a major diagnostic and research technique. It is valuable for the detection of parasites present at low concentrations in blood or serum samples. For several parasitic species, in particular for Plasmodium species, analysis of amplified products encoding polymorphic proteins allowed the discrimination not only of species, but also of subspecies or strains (BABIKER et al., 1994; FELGER et al., 1994; CONTAMIN et al., 1995; PAUL et al., 1995). Genetic traits, such as drug resistance, can easily be detected by PCR (PETERSON $e t$ al., 1990), provided the genetic locus is known. PCR amplification has been used with $P$. falciparum to study parasite diversity (FELGER et al., 1994; CONTAMIN et al., 1995), recombination rates (BABIKER et al., 1994), multiplicity of infections (BECK et al., in press) and the development and frequency of drug resistance. But very often sample material is limited, or material is not available for preparation of deoxyribonucleic acid (DNA). Historical samples, collected many years ago, are available only as fixed and stained microscope slides. In order to be able to use such samples for retrospective analyses, we attempred to utilize material isolated from fixed and stained malaria blood films. Here we present a reliable technique for PCR amplification using fixed and stained thick and thin blood films, previously used for microscopical diagnosis of $P$. falciparum, as a source of DNA for amplification.

\section{Material and Methods \\ Samples}

Blood slides were obtained from different locations; 112 were derived from the Wosera area of Papua New Guined, an area highly endemic for $P$. falciparum (for details see GENTON et al., 1995). Venous blood was collected and thick and thin blood films were made on separate slides, fixed and stained with $4 \%$ Giemsa's stain and examined at $1000 \times$ magnification. Four hundred microscope fields of a thick film were examined before the slide was declared negative. Most slides showed scanty parasitaemia; the mean density of positive slides was 1870 parasites $/ \mu \mathrm{L}$ of blood (range 40-4000 parasites). All thin films were used for PCR analysis, irrespective of the parasitaemia determined by microscopy of the thick films.

Address for correspondence: Hans-Peter Beck, Swiss Tropical Institute, Socinstrasse 57, $\mathrm{CH} 4002$ Basel, Switzerland; phone +41612848116, fax +4161271 8654, e-mail beckhp@ubaclu.unibas.ch
Further blood slides were collected from children in the Kilombero valley of Tanzania, an area holoendemic for P. falciparum (for details see SMITH et al., 1993). All slides were Giemsa-staincd and microscopically examined. Forty parasitaemic slides were selected from children presenting with more than 5000 parasites $/ \mu \mathrm{L}$ of blood and a temperature $>37.5^{\circ} \mathrm{C}$ (mean parasite density 111000 parasites $/ \mu \mathrm{L}$, range $2000-420000$ parasites). Blood from 10 children was also collected in tubes containing ethylenediaminetetraacetic acid for comparison. Another set of 10 slides collected one year previously and stored at room temperature was selected on the same criteria (mean density 94000 parasites $/ \mu \mathrm{L}$, range 8000-250000 parasites).

Additionally, thin films were prepared from a culture of $P$. falciparum (strain $\mathrm{K} 1$ ) at decreasing parasite concentrations from 10000 to 10 parasites $/ \mu \mathrm{L}$, and treated similarly.

\section{PCR analysis}

Two techniques were tried for DNA preparation from fixed and stained slides. Thick blood films derived from Tanzanian children were washed with ether and airdried. Subsequently, the slides were washed with 3 changes of $100 \mathrm{mM} \mathrm{Na}_{2} \mathrm{HPO}_{4}$ and the whole thick film (equivalent to approximately $4 \mu \mathrm{L}$ of blood; SHUTE, 1986) was scraped with a sterile scalpel blade into $10 \mu \mathrm{L}$ of $5 \mathrm{mM} \mathrm{Na} 2 \mathrm{HPO}_{4}$. After 2 washes in the same buffer, the remaining material was resuspended in $20 \mu \mathrm{L}$ of water and boiled for $10 \mathrm{~min}$. Five $\mu \mathrm{L}$ of the supernatant were used for the PCR. All slides were amplified in a nested PCR reaction for the gene for merozoite surface antigen (MSA) 1 as previously described (FOLEY et al., 1992). Amplified products were visualized on $1 \%$ agarose gels.

All thin blood films derived from Papua New Guinea and slides of cultured material were cleaned with chloroform and air-dried. Fifty $\mu \mathrm{L}$ of $10 \mathrm{mM}$ Tris buffer $(\mathrm{pH}$ $7 \cdot 2$ ) were spotted on to one-quarter of the dried blood on the thin film and the material (equivalent to approximately $0.35 \mu \mathrm{L}$ of blood; SHUTE, 1986) was wiped off within the buffer drop using sterile Whatman $3 \mathrm{MM}$ paper $\left(25 \mathrm{~mm}^{2}\right)$. To avoid cross-contamination between slides, forceps were briefly soaked in $2.5 \mathrm{~N} \mathrm{HCl}$ and flamed with ethanol. The filter paper was transferred to a $1.5 \mathrm{~mL}$ cup and treated with QIAamp Tissue- $\mathrm{Kit}^{\mathrm{TM}}$ (catalogue no. 29306, Qiagen, Hilden, Germany) according to the supplier's instructions for dried blood samples but, before addition of isopropanol, the filter paper was removed from the cup. PCR amplification for 
$P$ falciparum MSA2 was performed with one-third of the isolated DNA $(10 \mu \mathrm{L})$ as described previously (FELGER et al., 1993) and PCR products were visualized on $10 \%$ polyacrylamide gels. All negative PCR reactions were repeated with DNA from a second quarter of the thin blood film. In order to test the quality of the DNA, all the remaining negative samples were amplified for the human promoter for tumour necrosis factor (TNF) $\alpha$ using previously described primers (MCGUIRE et al., 1994). Ten $\mu \mathrm{L}$ of DNA were amplified in $100 \mu \mathrm{L}$ reactions containing $20 \mathrm{mM}$ Tris $(\mathrm{pH} 8.4), 50 \mathrm{mM} \mathrm{KCl}$, $3 \mathrm{mM} \mathrm{MgCl}, 0.25 \%$ Tween $20^{\circledR}, 10 \mu \mathrm{M}$ of each nucleotide, $0.1 \mu \mathrm{M}$ of each primer, and 1.5 units of Taq polymerase (Life Technologies). The amplification programme used was that previously described (MCGUIRE et al., 1994). Ten $\mu \mathrm{L}$ of amplified product were analysed on a $1.5 \%$ agarose gel.

\section{Results}

Thick blood films from Tanzanian children could be amplified by the nested PCR for MSA1, although 3 of 40 microscopically positive slides $(8 \%)$ failed to produce an amplification product. Storage for over one year did not influence the quality of DNA for PCR detection, and all 10 stored blood films yielded PCR products of equal quality.

Using the same technique as that used for the thick films from Tanzania, only a few of the samples from $\mathrm{Pa}-$ pua New Guinea, of which only thin films were available, produced an amplification signal. Therefore, an improved DNA purification system had to be used and affinity purification yielded the most sensitive and reliable results. Microscopical examination of 112 slides revealcd 68 with $P$. falciparum, 48 of which werc identified by PCR $(70 \%)$. Of the remaining 20 slides, 5 could not be amplified, either for $P$. falciparum MSA2 or for human TNF promoter as a control. Similarly, with 10 slides the TNF-promoter locus could be amplified only very weakly, indicating that only a limited amount of DNA had been recovered, and with 5 slides the TNF promoter region could be adequately amplified, but not the MSA2 locus. In addition, 4 slides on which parasites had not been detected by microscopy, gave a positive PCR result for MSA2

All the thin films derived from cultured material could be amplified for MSA2 by the nested PCR, to a minimum density of about 10 parasites $/ \mu \mathrm{L}$ of culture suspension.

\section{Discussion}

The ability to use Plasmodium DNA from fixed and stained microscope slides for the PCR is very valuable, and analysis of genetic markers directly from slides will be useful in cerrain applications. This technique can be used with samples from places where no facility exists for blood collection and storage, such as remote health stations, in basic epidemiological field studies, or by travellers to diagnose their illness retrospectively. Furthermore, in many places microscope slides have been kept for many years and it will be possible to use this valuable historical material to investigate, for example, the spread of drug resistance of $P$. falciparum or other genetic traits, when suitable markers become available. Only a few studies have been conducted on such historical material, all with only limited success, and in most cases the techniques were rather cumbersome and unreliable (KIMURA et al., 1994). The simple washing and boiling method which we used for DNA preparation with the Tanzanian slides appeared to be adequate for high parasitaemias, but it failed with low-grade infections such as those found on the slides from Papua Ncw Guinea, in particular when only thin films were available. Also, using only one-quarter of a thin blood film, as we did with the samples from Papua New Guinea, decreases the amount of blood tested to one-sixth of that on a whole thick blood film, as used with the Tanzanian material. It appears unlikely that differences in the method of cleaning the slides (ether versus chloroform) or amplification of different loci (MSA1 versus MSA2) were responsible for the difference between the 2 sets of slides. The sensitivity of the PCR has been reported to be similar when amplifying either locus (FOLEY et al., 1992). Hence, for thin films, affinity purification using simple DNA preparation kits seems to be the technique of choice when large numbers of samples have to be processed. This technique is easy and involves only a few handling steps, thus reducing the probability of cross-contamination. All infections with more than 3 parasites $/ 200$ microscope fields from Papua New Guinea were readily detected with this technique. The PCR amplification of a control template is a crucial necessity to test the quality of DNA used for amplification. A human marker gene is always present in approximately similar amounts in whole blood slides, and can be amplified. In 10 cases, detection of the control locus was only just above the detection limit, producing unly a weak band, and no $P$. falciparum PCR product could be obtained. In these cases, $P$. falciparum DNA may well have been scanty and below the detection limit of the PCR. This may explain the negative results obtained with microscopically positive slides, all of which had only one or 2 parasites per 200 fields of the thick film. Similarly, the 5 slides from which the TNF promoter locus could easily be amplified, but not the MSA2 locus, all had scanty parasitaemia with one or 2 parasites per 200 fields. All but one also had mixed infections with $P$. falciparum and $P$. vivax or $P$. malariae reported by microscopy, therefore an error in identification during slide examination cannot be excluded. On the other hand, the PCR was able to detect 4 infections which were overlooked by microscopy. It is well established that the PCR, under optimal conditions and with sufficient volume, is better than microscopy at detecting low parasitaemias (FELGER et al, 1995). In conclusion, DNA isolated from fixed and stained blood films used for malaria diagnosis can be used for PCR analysis. Certainly, this will not be the starting material of choice for large scale studies or accurate assessment of parasite prevalence, when blood samples can be collected conventionally, but it may enable researchers to study and analyse amplified DNA for several purposes from blood films collected before the development of the PCR.

\section{Acknowledgements}

We are grateful to the field teams and microscopists at the Papua New Guinea Institute of Medical Research and the Ifakara Centre, Tanzania. We also thank Dr H. Matille, Hoffmann-LaRoche, for providing cultured material of $P$. falciparum (K1). This work was partly funded through Schweizerischen Nationalfond, project no. 3200-045616.95/1.

\section{References}

Babiker, H. A., Ranford-Cartwright, L. C., Currie, D., Charlwood, J. D., Billingsley, P., Teuscher, T. \& Walliker, D. (1994). Random mating in a natural population of the malaria parasite Plasmodium falciparum. Parasitology, 109 , 413-421.

Beck, H. P., Felger, I., Huber, W., Steiger, S., Smith, T., Weiss, N., Alonso, P. L. \& Tanner, M. (in press). Analysis of multiple Plasmodium falcipurum infections in Tanzanian children during the phase III trial of the malaria vaccine SPf66. Fournal of Infectious Diseases.

Contamin, H., Fandcur, T., Bonncfoy, S., Skouri, F., Ntoumi, F. \& Mercereau-Puijalon, O. (1995). PCR typing of field isolates of Plasmodium falciparum. Fournal of Clinical Microbiology, 33, 944-951.

Felger, I., Tavul, L. \& Beck, H. P. (1993). Plasmodium falciparum: a rapid technique for genotyping the merozoite surface protein 2. Experimental Parasitology, 77, 372-377.

Felger, I., Tavul, L., Kabintik, S., Marshall, V., Genton, B., Alpers, M. \& Beck, H. P. (1994). Plasmodium falciparum: extensive polymorphism in merozoite surface antigen 2 alleles in an area with endemic malaria in Papua New Guinea. $E x$ perimental Parasitology, 79, 106-116.

Felger, I., Tavul, L., Narara, A., Genton, B., Alpers, M. \& 
Beck, H. P. (1995). The use of the polymerase chain reaction for more sensitive detection of Plasmodium falciparum. Papua New Guinea Medical fournal, 38, 52-56.

Foley, M., Ranford-Cartwright, L. C. \& Babiker, H. A. (1992). Rapid and simple method for isolating malaria DNA from fingerprick samples of blood. Molecular and Biochemical Parasitology, 53, 241-244.

Genton, B., Al-Yaman, F., Beck, H. P., Hii, J., Mellor, S., Rare, L., Ginny, M., Smith, T. \& Alpers, M. P. (1995). The epidemiology of malaria in the Wosera area, East Sepik Province, Papua New Guinea, in preparation for vaccine trials. II. Mortality and morbidity. Annals of Tropical Medicine and Parasitology, 89, 377-390.

Kimura, M., Kaneko, O., Inoue, A., Ishii, A. \& Tanabe, K. (1995). Amplification by polymerase chain reaction of Plasmodium falciparum DNA from Giemsa-stained thin blood smears. Molecular and Biochemical Parasitology, 70, 193-197. McGuire, W., Hill, A. V. S., Allsopp, C. E. M., Greenwood, B. M. \& Kwiatkowski, D. (1994). Variation in the TNF- $\alpha$ promoter region associated with susceptibility to cerebral malaria. Nature, 371, 508-511.
Paul, R. E., Packer, M. J, Walmsley, M., Lagog, M., Ranford Cartwright, L. C., Paru, R. \& Day, K. P. (1995). Mating patterns in malaria parasite populations of Papua New Guinea. Science, 269, 1709-1711.

Peterson, D. S., Milhous, W. K. \& Wellems, T. E. (1990). Molecular basis of differential resistance to cycloguanil and pyrimethamine in Plasmodium falciparum malaria. Proceedings of the National Academy of Sciences of the USA, 87, 3018-3022.

Shute, G. (1986). The microscopic diagnosis of malaria. In Malaria, Wernsdorfer, W. \& McGregor, I. (editors). Edinburgh: Churchill Livingstone, pp. 781-814.

Smith, T. A., Charlwood, J. D., Kihonda, J., Mwankuye, S. Billingsley, P., Meuwissen, J., Lyimo, E., Takken, W., Teuscher, T. \& Tanner, M. (1993). Absence of seasonal variation in malaria parasitaemia in an area of extremely high, but seasonal transmission. Acta Tropica, 54, 55-72.

Received 30 September 196; revised 28 November 1996; accepted for publication 28 November 1996

\section{Short Report}

\section{An alternative to serum for cultivation of Plasmodium falciparum in vitro}

\author{
Susan L. Cranmer ${ }^{\star}$, Cathleen Magowan ${ }^{2}$, Joy \\ Liang $^{2}$, Ross L. Coppe ${ }^{1}$ and Brian M. Cooke ${ }^{1}$ \\ ${ }^{I}$ Department of Microbiology, Monash University, Clayton \\ 3168, Victoria, Australia; ${ }^{2}$ Life Sciences Division, Law- \\ rence Berkeley Laboratory, Berkeley, California 94720 , \\ $U S A$
}

Keywords: malaria, Plasmodium falciparum, cultivation in vitro, serum substitute

It is generally accepted that optimum growth of the malaria parasite Plasmodium falciparum in vitro is dependent on the presence of human serum in the culture medium. Numerous disadvantages associated with human serum, including variation in its growth-promoting effectiveness between different batches (JENSEN, 1979; DIVO \& JENSEN, 1982; ZOLG et al., 1982), which neccessitates batch testing, limited availability, relatively high cost, requirement for frozen storage, necessity for red cell/serum $\mathrm{ABO}$ group compatibility, and the obvious biohazard considerations, continue to provide an impetus toward the development of serum substitutes. Several alternative supplements, some quite complex, have been described; however, in general, these have been less effective at supporting parasite growth than serum-supplemented media, their effectiveness has been strain specific, or the parasites have required several weeks of culture to adapt to the new medium (IFEDIBA \& VANDERBERG, 1980; SAX \& RIECKMANN, 1980; WILLET \& CANFIELD, 1984; RAMOS et al., 1986; OFULLA et al., 1993; ASAHI \& KANAZAWA, 1994). Thus, although there is a great need for a suitable replacement, human serum remains the most widely used supplement in malaria culture media.

^Present address: Monash University Department of Medicine, Box Hill Hospital, Box Hill 3128, Victoria, Australia. Address for correspondence: Dr B. M. Cooke, Department of Microbiology, Monash University, Clayton 3168, Victoria Australia; phone +6139905 4827, fax +61 399054811 , email: brian.cooke@med.monash.edu.au
During the past 3 years, we have been successfully culturing $P$. falciparum without human serum using RPMI 1640 medium supplemented with a commercially available lipid-rich bovine serum albumin called Albumax $\mathrm{II}^{(\mathbb{R})}$ (Gibco BRL, Grand Island, New York, USA). To our surprise, a literature search revealed no report comparing growth of $P$. falciparum in media supplemented with Albumax II ${ }^{\circledR}$ with growth in serum-supplemented media. Onc recent report (GEROLD et al.,
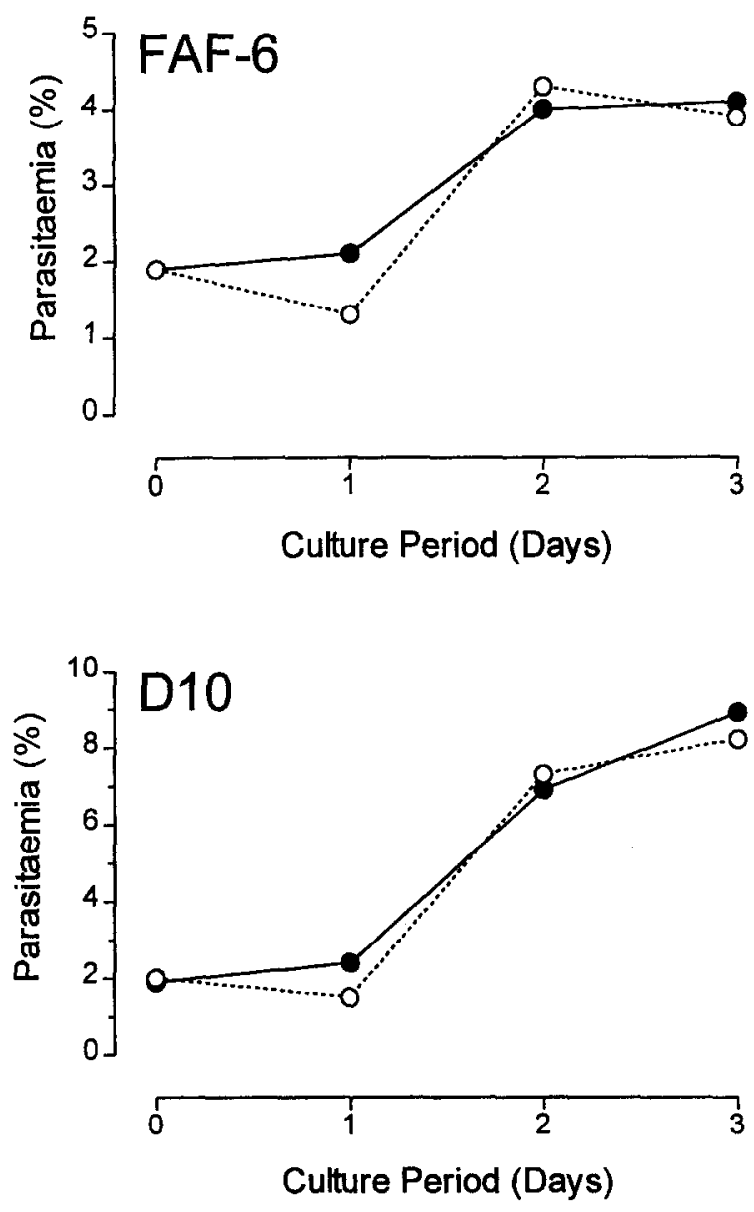

Fig. 1. Two separate experiments comparing growth of 2 different lines of $P$ falciparum (FAF-6 and DI0) in RPMI-S (O) or RPMI-A ( ) medium for 3 consecutive days. 